\title{
THE ANALYSIS OF MECHANICAL CHARACTERISTICS OF POLYESTER SEWING THREADS FROM STAPLE FIBERS
}

Nenad Ćirković*, Nataša Stamenković, Tatjana Šarac, Jovana Stepanović

Faculty of Technology, Leskovac, Serbia

Joining of the parts of clothing items in the clothing industry is mostly done with sewing threads, of which polyester threads occupy a significant place. At the joining places e.g sewing, together with the seams and stitches, the threads should provide adequate comfort to the garment. The characteristics of the seams will also depend on their characteristics. The paper analyzes polyester threads from staple fibers, linear density from 23 tex to 48 tex. The dependences between the mechanical characteristics of the threads and the threads in the loop, as well as their mutual relations by the corresponding coefficients are presented. The obtained results can be used by manufacturers of sewing threads and clothes in the design and the selection of threads for the purpose of predicting the mechanical characteristics of seams on garments.
(ORIGINAL SCIENTIFIC PAPER) UDC 677.072.6:677.494.674

Keywords: polyester thread, mechanical characteristics of thread and loop thread

\section{Introduction}

During the exploitation of textile materials, their dimensions change (usually by stretching). It is the same with sewing threads. Therefore, the basic task when designing the process of their processing (e.g. sewing parts of clothes) is to predict the allowable loads that would not cause the occurrence of permanent deformations.

Quantities such as elasticity limit, tensile strength and residual deformations describe the deformation characteristics of the threads under the action of a certain tensile force. Knowing these characteristics under the action of a constant or variable force will enable the correct design of the technological process of sewing.

Due to the specific internal structure of fibers (complex polymeric materials), all three types of deformations (elastic, viscoelastic and plastic) appear at the same time during their loading, so that their rheological constants cannot be determined as in elastic materials. This problem is emphasized in single-thread and finished yarns, i.e. the threads in which it is additionally difficult to determine rheological constants due to their complex internal structure and the way of connecting the basic structural elements in them [1].

Mechanical properties determine the ability of sewing threads to resist the action of various external forces that can cause different types of deformations (shear, compression, stretching, twisting, bending, complete destruction, etc.). As a result of the action of these forces, there are changes in the shape and dimensions (i.e. external appearance) and disturbances in the structure. The magnitude of the induced deformation depends on the type, intensity, manner and time of action of the force, as well as on the time of relaxation and rest [2,3]

Some studies have shown that even small loads of textile materials cause residual (plastic) deformations. Therefore, the elastic limit means the stress which, after unloading and resting for one minute, does not leave behind a deformation greater than $0,1 \%$ (relative elongation). In other studies, half of the initial modulus is recommended for the allowable load limit (initial modulus - force causing a relative elongation of $1 \%$ ) [4,5]. For the load limit, the so-called elastic limit to the "module" curve is used which is the first derivative of the force by relative elongation based on the curve $F-\varepsilon[5,6]$.

Depending on the mode of action of the load, there are three groups of mechanical characteristics of yarns and threads: semi-cyclic, single-cycle and multi-cycle [7]. Semi-cyclic yarns and threads are obtained by testing during the action of the load, single-cyclic during the whole cycle load-unloading-rest and multi-cyclic during the action of the whole cycle several times. Depending on the material tear during testing, i.e. until complete disruption of the structure or not, the semi-cyclic and multicyclic characteristics can be intermittent and continuous $[2,8]$.

\section{Experimental}

\section{Material and methods}

Polyester sewing threads made of "high strength" staple fibers were used for the experimental part in the work. The characteristics of the fibers according to the

\footnotetext{
*Author address: Nenad Ćirković, Faculty of Technology,

Bulevar oslobodjenja 124, 16000 Leskovac, Serbia

E-mail: nenadcira@gmail.com

The manuscript received: May, 18, 2020.

Paper accepted: May, 30, 2020.
} 
manufacturer's specification are: length $38 \div 40 \mathrm{~mm}$, linear density 0,133 tex (1,2 den), relative breaking force $>65 \mathrm{cN} \cdot$ tex $^{-1}$, breaking elongation 25\%. 25 threads of different linear density from 23 tex to 48 tex were used, which have two (threads from 1 to 18) and three yarns (threads from 9 to 25 ) in the structure.

The following methods were used:

- SRPS EN 12751:2008 Textiles - Sampling of fibres, yarns and fabrics for testing

- SRPS EN ISO 139:2007/A1:2014 Textiles - Standard atmospheres for conditioning and testing - Amendment 1

- SRPS EN ISO 2060:2012 Textiles - Yarn from packages - Determination of linear density (mass per unit length) by the skein method

- Koehlin formula for thread twist coefficient

- SRPS EN ISO 2061:2016 Textiles - Determination of twist in yarns - Direct counting method

- SRPS EN ISO 2062:2012 Textiles - Yarns from packages - Determination of single-end breaking force and elongation at break using a constant rate of extension (CRE) tester (also for the mechanical characteristics of the thread of the loop).

According to the function of the curve $F-\varepsilon$, with the appropriate software, the values of forces and elongations at the first irreversible change in the structure of the thread and the thread of the loop, as well as the upper load limits were determined.

Uster Autosorter 3 and Tinius Olsen H5KS were used as test devices.

\section{Results and discussion}

Before each use of materials in the further production process, it is necessary to check their characteristics. Table 1 shows the test results of linear density $T_{t}$, number of twist $T$, thread twist coefficient $\alpha_{t}$, breaking force $F_{t}$, breaking elongation $\varepsilon_{t}$, relative breaking force $F_{r t}$, breaking force in loop $F_{l}$, breaking elongation in loop $\varepsilon_{l}$.

Table 1. Results of testing the characteristics of polyester sewing threads and threads in the loop

\begin{tabular}{ccccccccc}
\hline $\begin{array}{c}\text { Sewing } \\
\text { thread } \\
1\end{array}$ & $\begin{array}{c}T_{t} \\
(\mathrm{tex})\end{array}$ & $\begin{array}{c}T \\
\left(\mathrm{~m}^{-1}\right)\end{array}$ & $\alpha_{t}$ & $\begin{array}{c}F_{t} \\
(\mathrm{cN})\end{array}$ & $\begin{array}{c}\varepsilon_{t} \\
(\%)\end{array}$ & $\begin{array}{c}F_{t} \\
\left(\mathrm{cN} \cdot \mathrm{ce}^{-1}\right)\end{array}$ & $\begin{array}{c}F_{l} \\
(\mathrm{cN})\end{array}$ & $\begin{array}{c}\varepsilon \\
(\%)\end{array}$ \\
\hline 1 & 23,2 & 1105 & 5322 & 631 & 14,45 & 27,19 & 1108 & 14,12 \\
2 & 23,6 & 1076 & 5227 & 674 & 16,02 & 28,56 & 1042 & 15,12 \\
3 & 25,1 & 1074 & 5381 & 694 & 16,02 & 27,65 & 1290 & 15,51 \\
4 & 25,5 & 1064 & 5373 & 733 & 15,56 & 28,73 & 1072 & 14,66 \\
5 & 26,0 & 1060 & 5405 & 805 & 18,98 & 30,97 & 1388 & 18,02 \\
6 & 26,3 & 996 & 5112 & 838 & 18,98 & 31,81 & 1392 & 18,37 \\
7 & 27,6 & 985 & 5175 & 838 & 17,95 & 30,38 & 1490 & 17,54 \\
8 & 28,0 & 981 & 5191 & 849 & 18,38 & 30,33 & 1554 & 17,90 \\
9 & 28,7 & 952 & 5100 & 872 & 20,36 & 30,37 & 1504 & 18,33 \\
10 & 29,3 & 903 & 4888 & 872 & 14,21 & 29,78 & 1590 & 13,75 \\
11 & 30,0 & 898 & 4919 & 881 & 16,81 & 29,36 & 1694 & 15,26 \\
12 & 30,7 & 870 & 4820 & 896 & 16,29 & 29,17 & 1732 & 15,87 \\
13 & 31,6 & 865 & 4863 & 970 & 15,19 & 30,71 & 1612 & 14,82 \\
14 & 32,2 & 848 & 4812 & 1095 & 14,40 & 34,01 & 1744 & 14,07 \\
15 & 33,3 & 845 & 4876 & 1121 & 15,62 & 33,66 & 1808 & 14,34 \\
16 & 34,2 & 814 & 4762 & 1132 & 19,50 & 33,09 & 1994 & 16,38 \\
17 & 35,6 & 788 & 4702 & 1163 & 15,55 & 32,68 & 1630 & 14,87 \\
18 & 36,1 & 781 & 4693 & 1173 & 20,25 & 32,50 & 1636 & 19,75 \\
19 & 38,9 & 763 & 4759 & 1195 & 16,44 & 30,72 & 2128 & 16,11 \\
20 & 39,5 & 758 & 4766 & 1240 & 15,14 & 31,36 & 2078 & 14,14 \\
21 & 40,5 & 757 & 4818 & 1240 & 15,90 & 30,62 & 2022 & 15,35 \\
22 & 41,6 & 756 & 4878 & 1255 & 15,70 & 30,14 & 1982 & 13,29 \\
23 & 44,7 & 704 & 4705 & 1325 & 20,60 & 29,67 & 2080 & 16,89 \\
24 & 45,9 & 696 & 4713 & 1430 & 16,62 & 31,18 & 2264 & 16,08 \\
25 & 48,0 & 674 & 4668 & 1576 & 20,98 & 32,86 & 2432 & 17,27 \\
\hline
\end{tabular}

According to the results shown in Table 1, Figure 1 shows the dependence of the breaking force of the thread in the loop on the breaking force of the thread, and Figure 2 shows the dependence of the breaking elongation of the thread in the loop on the breaking elongation of the thread.

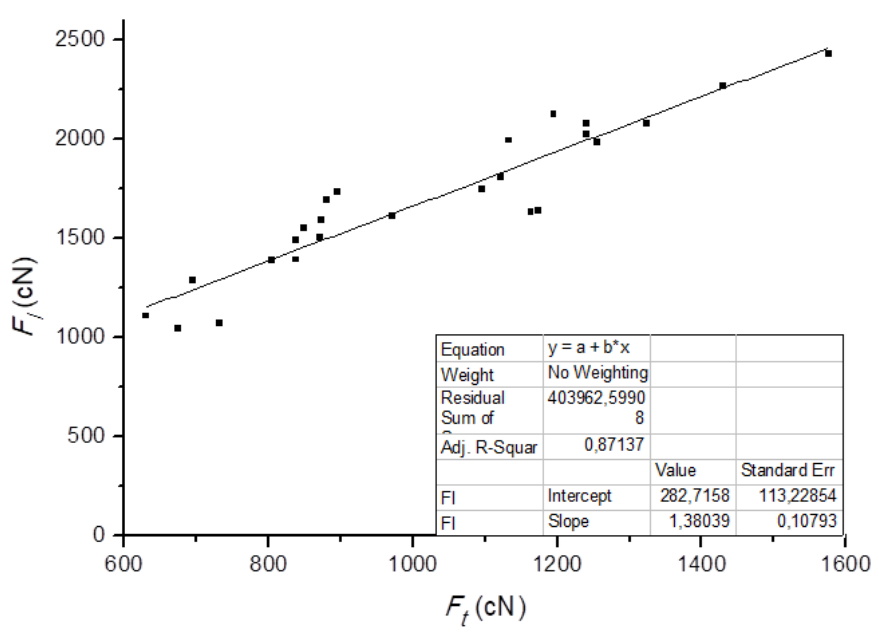

Figure 1. Dependence of the breaking force of the thread in the loop on the breaking force of the thread

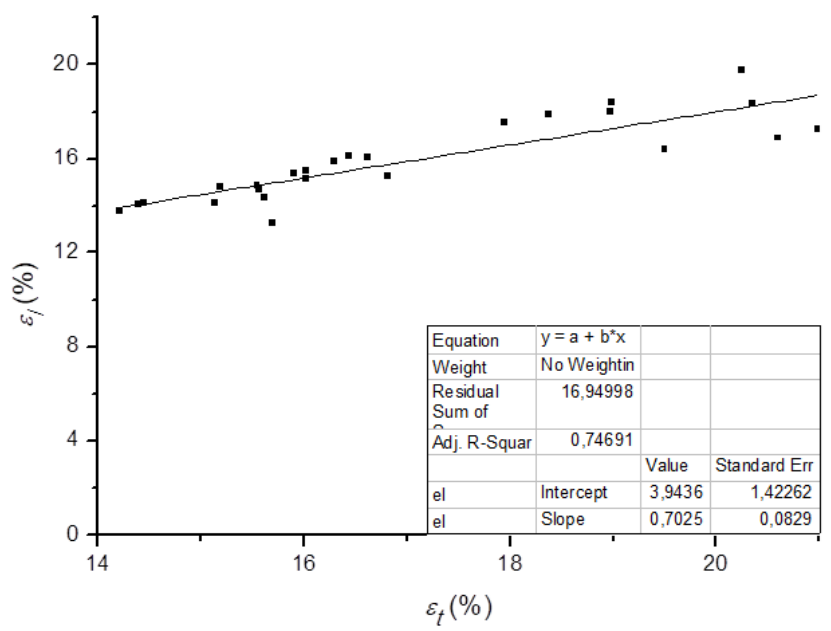

Figure 2. Dependence of the breaking elongation of the thread in the loop on the breaking elongation of the thread

From the Figures, it can be noticed that the dependencies between these characteristics are quite satisfactory in terms of the functional dependence, which is confirmed by the values of Adj. R-Squar ( 0.871 and 0.746 ) and can be represented by the corresponding functional equations ( 1 i 2 ):

$F_{l}=282,7158+1,38039 \cdot F_{t}$

$\varepsilon_{l}=3,9436+0,7025 \cdot \varepsilon_{t}$

These dependencies can be used in predicting the breaking characteristics of sewing threads in a loop, and further used for breaking characteristics of seams. 
Table 2 shows the values of deformation characteristics of threads and the threads in the loop determined on the basis of force-elongation curves: force at the first irreversible change in the thread structure Ft1, elongation at the first irreversible change in the thread structure $\varepsilon_{t 1}$, force at the upper limit of the thread load $F_{t 2}$, elongation at the upper thread load limit $\varepsilon_{t 2}$, force at the first irreversible change in the thread structure in the loop $F_{11}$, elongation at the first irreversible change in the thread structure in the loop $\varepsilon_{11}$, force at the upper thread load limit in the loop $F_{12}$, elongation at the upper limit thread loads in the loop $\varepsilon_{12}$.

Table 2. Values of deformation characteristics of polyester sewing threads and threads in the loop

\begin{tabular}{|c|c|c|c|c|c|c|c|c|}
\hline $\begin{array}{l}\text { Sewing } \\
\text { thread }\end{array}$ & $F_{t 1}(\mathrm{cN})$ & $\varepsilon_{11}(\%)$ & $F_{t 2}(\mathrm{cN})$ & $\varepsilon_{22}(\%)$ & $F_{11}(\mathrm{cN})$ & $\sigma_{11}(\%)$ & $F_{12}(\mathrm{cN})$ & $\varepsilon_{2}(\%)$ \\
\hline 1 & $11{ }^{2} 8$ & 2,16 & 537 & 12,76 & $2{ }^{6} 21$ & 2,92 & ${ }^{8}$ & 13,16 \\
\hline 2 & 112 & 2,56 & 618 & 15,16 & 227 & 3,04 & 832 & 13,32 \\
\hline 3 & 121 & 2,24 & 555 & 14,00 & 263 & 3,24 & 1153 & 15,00 \\
\hline 4 & 115 & 2,28 & 671 & 14,88 & 238 & 2,84 & 1046 & 14,04 \\
\hline 5 & 145 & 2,28 & 792 & 15,64 & 328 & 3,20 & 1431 & 15,84 \\
\hline 6 & 113 & 2,24 & 522 & 14,96 & 273 & 2,92 & 1163 & 16,28 \\
\hline 7 & 96 & 1,92 & 560 & 15,24 & 296 & 3,12 & 1257 & 15,76 \\
\hline 8 & 170 & 2,36 & 808 & 15,84 & 326 & 2,80 & 1497 & 16,12 \\
\hline 9 & 144 & 2,64 & 635 & 16,20 & 265 & 3,04 & 1097 & 15,68 \\
\hline 10 & 155 & 1,84 & 710 & 12,04 & 336 & 2,44 & 1426 & 12,68 \\
\hline 11 & 190 & 2,12 & 846 & 14,16 & 264 & 2,52 & 1283 & 13,48 \\
\hline 12 & 170 & 2,12 & 658 & 13,72 & 449 & 3,44 & 1462 & 14,96 \\
\hline 13 & 126 & 1,84 & 585 & 14,80 & 304 & $\begin{array}{l}2,84 \\
2,84\end{array}$ & 1085 & 14,68 \\
\hline 14 & 172 & 1,80 & 943 & 13,96 & 307 & 2,36 & 1519 & 13,28 \\
\hline 15 & 215 & 2,04 & 1076 & 14,12 & 457 & 2,64 & 1811 & 13,36 \\
\hline 16 & 211 & 2,24 & 1021 & 16,16 & 445 & 2,80 & 1688 & 15,08 \\
\hline 17 & 218 & 2,48 & 769 & 13,24 & 361 & 2,84 & 1483 & 14,08 \\
\hline 18 & 196 & 2,24 & 689 & 13,60 & 323 & 3,20 & 1213 & 15,56 \\
\hline 19 & 259 & $\begin{array}{l}2,24 \\
2,00\end{array}$ & 1071 & 13,88 & 556 & $\begin{array}{l}2,<0 \\
2,48\end{array}$ & 2118 & $\begin{array}{l}14,08 \\
\end{array}$ \\
\hline 20 & 256 & 1,76 & 1229 & 14,88 & 450 & 2,04 & 2130 & 14,72 \\
\hline 21 & 185 & 1,92 & 694 & 14,64 & 189 & 2,48 & 1302 & 16,24 \\
\hline 22 & 174 & $\begin{array}{l}1,84 \\
\text { S }\end{array}$ & 845 & 12,72 & 328 & 2,12 & 1390 & 12,04 \\
\hline 23 & 228 & 2,32 & 1131 & 14,96 & 399 & 2,48 & 2012 & 15,20 \\
\hline 24 & 212 & 2,36 & 856 & 13,32 & 394 & 2,48 & 1858 & 14,56 \\
\hline 25 & 211 & 2,00 & 1337 & 15,72 & 419 & 2,44 & 2390 & 16,00 \\
\hline
\end{tabular}

Table 3. Coefficients of mutual relations of mechanical and deformation characteristics of polyester sewing threads and threads in a loop in relation to breaking characteristics of threads

\begin{tabular}{|c|c|c|c|c|c|c|c|c|c|c|c|c|}
\hline $\begin{array}{l}\text { Sewing } \\
\text { thread }\end{array}$ & $\frac{F_{l}}{F_{t}}$ & $\frac{\varepsilon_{l}}{\varepsilon_{t}}$ & $\frac{F_{t 1}}{F_{t}}$ & $\frac{F_{t 2}}{F_{t}}$ & $\frac{F_{l 1}}{F_{t}}$ & $\frac{F_{l 2}}{F_{t}}$ & $\frac{\frac{\varepsilon_{t 1}}{\varepsilon_{t}}}{\varepsilon_{s}}$ & $\frac{\varepsilon_{t 2}}{\varepsilon_{t}}$ & $\frac{\varepsilon_{l 1}}{\varepsilon_{t}}$ & $\frac{\frac{\varepsilon_{l 2}}{\varepsilon_{t}}}{11}$ & $\frac{\varepsilon_{l 1}}{\varepsilon_{t 1}}$ & $\frac{\varepsilon_{l 2}}{\varepsilon_{t 2}}$ \\
\hline 1 & 1,76 & 0,98 & 0,19 & $\begin{array}{c}5,85 \\
0,85\end{array}$ & $\begin{array}{c}6 \\
0,35\end{array}$ & $\begin{array}{c}1,44 \\
\end{array}$ & 0,15 & $\stackrel{9}{0,88}$ & 0,20 & 0,91 & 1,35 & 1,03 \\
\hline 2 & 1,55 & 0,94 & 0,17 & 0,92 & 0,34 & 1,23 & 0,16 & 0,95 & 0,19 & 0,83 & 1,19 & 0,88 \\
\hline 3 & 1,86 & 0,97 & 0,17 & 0,80 & 0,38 & 1,66 & 0,14 & 0,87 & 0,20 & 0,94 & 1,45 & 1,07 \\
\hline 4 & 1,46 & 0,94 & 0,16 & 0,92 & 0,32 & 1,43 & 0,15 & 0,96 & 0,18 & 0,90 & 1,25 & 0,94 \\
\hline 5 & 1,72 & 0,95 & 0,18 & 0,98 & 0,41 & 1,78 & 0,12 & 0,82 & 0,17 & 0,83 & 1,40 & 1,01 \\
\hline 6 & 1,66 & 0,97 & 0,14 & 0,62 & 0,33 & 1,39 & 0,12 & 0,79 & 0,15 & 0,86 & 1,30 & 1,09 \\
\hline 7 & 1,78 & 0,98 & 0,11 & 0,67 & 0,35 & 1,50 & 0,11 & 0,85 & 0,17 & 0,88 & 1,63 & 1,03 \\
\hline 8 & 1,83 & 0,97 & 0,20 & 0,95 & 0,38 & 1,76 & 0,13 & 0,86 & 0,15 & 0,88 & 1,19 & 1,02 \\
\hline 9 & 1,73 & 0,90 & 0,17 & 0,73 & 0,30 & 1,26 & 0,13 & 0,80 & 0,15 & 0,77 & 1,15 & 0,97 \\
\hline 10 & 1,82 & 0,97 & 0,18 & 0,81 & 0,38 & 1,63 & 0,13 & 0,85 & 0,17 & 0,89 & 1,33 & 1,05 \\
\hline 11 & 1,92 & 0,91 & 0,22 & 0,96 & 0,30 & 1,46 & 0,13 & 0,84 & 0,15 & 0,80 & 1,19 & 0,95 \\
\hline 12 & 1,93 & 0,97 & 0,19 & 0,73 & 0,50 & 1,63 & 0,13 & 0,84 & 0,21 & 0,92 & 1,62 & 1,09 \\
\hline 13 & 1,66 & 0,98 & 0,13 & 0,60 & 0,31 & 1,12 & 0,12 & 0,97 & 0,19 & 0,97 & 1,54 & 0,99 \\
\hline 14 & 1,59 & 0,98 & 0,16 & 0,86 & 0,28 & 1,39 & 0,13 & 0,97 & 0,16 & 0,92 & 1,31 & 0,95 \\
\hline 15 & $\begin{array}{l}1,61 \\
\text { a }\end{array}$ & 0,92 & 0,19 & 0,96 & 0,41 & $\begin{array}{l}1,62 \\
1,62\end{array}$ & 0,13 & 0,90 & 0,17 & & 1,29 & \\
\hline 16 & 1,76 & 0,84 & 0,19 & 0,90 & 0,39 & 1,49 & 0,11 & 0,83 & 0,14 & 0,77 & 1,25 & 0,93 \\
\hline 17 & 1,40 & 0,96 & 0,19 & 0,66 & 0,31 & 1,27 & 0,16 & 0,85 & 0,18 & 0,91 & 1,15 & 1,06 \\
\hline 18 & 1,39 & 0,98 & 0,17 & 0,59 & 0,28 & 1,03 & 0,11 & 0,67 & 0,16 & 0,77 & 1,43 & 1,14 \\
\hline 19 & 1,78 & 0,98 & 0,22 & 0,90 & 0,46 & 1,77 & 0,12 & 0,84 & 0,15 & 0,86 & 1,24 & 1,01 \\
\hline 20 & 1,68 & 0,93 & 0,21 & 0,99 & 0,36 & 1,72 & 0,12 & 0,98 & 0,13 & 0,97 & 1,16 & 0,99 \\
\hline 21 & 1,63 & 0,97 & 0,15 & 0,56 & 0,15 & 1,05 & 0,12 & 0,92 & 0,16 & 1,02 & 1,29 & 1,11 \\
\hline 22 & 1,58 & 0,85 & 0,14 & 0,67 & 0,26 & 1,11 & 0,12 & 0,81 & 0,14 & 0,77 & 1,15 & 0,95 \\
\hline 23 & 1,57 & 0,82 & 0,17 & 0,85 & 0,30 & 1,52 & 0,11 & 0,73 & 0,12 & 0,74 & 1,07 & 1,02 \\
\hline 24 & 1,58 & 0,97 & 0,15 & 0,60 & 0,28 & 1,30 & 0,14 & 0,80 & 0,15 & 0,88 & 1,05 & 1,09 \\
\hline 25 & 1,54 & 0,82 & 0,13 & 0,85 & 0,27 & 1,52 & 0,10 & 0,75 & 0,12 & 0,76 & 1,22 & 1,02 \\
\hline $\bar{x}_{p}$ & 1,67 & 0,94 & 0,17 & 0,80 & 0,34 & 1,44 & 0,13 & 0,85 & 0,16 & 0,86 & 1,29 & 1,01 \\
\hline $\begin{array}{c}S D \\
C V(\%)\end{array}$ & $\begin{array}{l}0,15 \\
8,83\end{array}$ & $\begin{array}{l}0,05 \\
5,53\end{array}$ & $\begin{array}{c}0,03 \\
16,12\end{array}$ & $\begin{array}{c}0,14 \\
17,71\end{array}$ & $\begin{array}{c}0,07 \\
21,45\end{array}$ & $\begin{array}{c}0,23 \\
15,73\end{array}$ & $\begin{array}{c}0,02 \\
12,38\end{array}$ & $\begin{array}{l}0,08 \\
9,16\end{array}$ & $\begin{array}{c}0,02 \\
15,15\end{array}$ & $\begin{array}{l}0,07 \\
8,62\end{array}$ & $\begin{array}{c}0,15 \\
12,01\end{array}$ & $\begin{array}{l}0,07 \\
6,41\end{array}$ \\
\hline$p_{\bar{x}}$ & $\pm 0,06$ & $\pm 0,02$ & $\pm 0,01$ & $\pm 0,06$ & $\pm 0,03$ & $\pm 0,09$ & $\pm 0,01$ & $\pm 0,03$ & $\pm 0,01$ & $\pm 0,03$ & $\pm 0,06$ & $\pm 0,03$ \\
\hline
\end{tabular}

In order to be able to use the stated values of thread characteristics (from Tables 1 and 2) for further analysis, Table 3 shows the coefficients of mutual relations of these quantities and breaking characteristics with statistical processing.

It can be seen from Table 3 that based on the results, the coefficients of ratio (i.e. share) of breaking characteristics of threads in the loop (columns 2 and 3), deformation characteristics of threads (columns 4, 5, 8 and 9), deformation characteristics of the threads in loops (columns 6, 7, 10 and 11) with breaking characteristics of the threads, and also the deformation characteristics of the threads in the loop (columns 12 and 13) with the deformation characteristics of the threads (columns 12 and 13). These relations can also be represented by the equations $(3 \div 14)$ :

$$
\begin{aligned}
& F_{l}=(1,61 \div 1,73) \cdot F_{t} \cdots \ldots \\
& \varepsilon_{l}=(0,92 \div 0,96) \cdot \varepsilon_{t} \cdots \\
& F_{t 1}=(0,16 \div 0,18) \cdot F_{t} \cdots \\
& F_{t 2}=(0,74 \div 0,86) \cdot F_{t} \cdots \\
& F_{l 1}=(0,31 \div 0,37) \cdot F_{t} \cdots \\
& F_{l 2}=(1,35 \div 1,53) \cdot F_{t} \cdots \\
& \varepsilon_{t 1}=(0,12 \div 0,14) \cdot \varepsilon_{t} \cdots \\
& \varepsilon_{t 2}=(0,82 \div 0,88) \cdot \varepsilon_{t} \cdots \\
& \varepsilon_{/ 1}=(0,15 \div 0,17) \cdot \varepsilon_{t} \cdots \\
& \varepsilon_{l 2}=(0,83 \div 0,89) \cdot \varepsilon_{t} \cdots \\
& \varepsilon_{/ 1}=(1,23 \div 1,35) \cdot \varepsilon_{t 1} \cdots \\
& \varepsilon_{/ 2}=(0,98 \div 1,04) \cdot \varepsilon_{t 2} \cdots
\end{aligned}
$$

These equations essentially represent what proportion of the breaking characteristics of the threads is contained in the deformation and breaking characteristics of the threads and the threads in the loop.

\section{Conclusion}

When wearing clothes, it is exposed to atmospheric, physical and chemical influences, and especially to stresses. The stress of the material depends on the movement of the body, the cut of the garment, the way it is made, the material, etc. Excessive stresses can lead to damage and deformation of clothing that occur on the materials in the area of the seam, the seam itself (thread break) and less often on the material itself.

Based on the results presented in the paper, it is possible to predict the relations, i.e. mutual relations of mechanical and deformation characteristics of sewing threads and threads in the loop: breaking forces and 
elongations of threads and threads in the loop, forces and elongations at the first irreversible change in the structure of threads and threads in the loop, forces and elongations at the upper load limit of threads and threads in the loop. Thanks to these relations, the share of breaking characteristics of the threads contained in the deformation, and breaking characteristics of the threads and the threads in the loop can be defined.

Therefore, the basic task in designing the process of making sewing threads and their use (e.g. sewing parts of clothes) is to predict the allowable loads that would not cause the occurrence of permanent deformations.

\section{Acknowledgement}

The Republic of Serbia - Ministry of Education, Science and Technological Development, Program for financing scientific research, ev. no. 451-03-68/2020$14 / 200133$

\section{References}

[1] H. M. Wan, X. G. Wang, The fineness variation of degummed hemp fibers, International Development of Kenaf and Allied Fibers-Proceedings of the International Kenaf Symposium, Minneapolis, MN, U.S.A. (2004) 127136.

[2] Г.Н.Кукин, Л.Н.Соловьев, Л.И.Кобляков, Текстильное материаловедение (волокна и нити), Легпромбытиздат, Москва, 1989., р. 119.
[3] J. Stepanovic, D. Radivojevic, V. Petrovic, C. Besic, Projecting of deformation characteristics of single and twisted wool yarns, Industria textila, 61(3) (2010) 95-105.

[4] Y. P. Zhang, X. G. Wang, The effect of along-fibre diameter variation on fibre tensile behaviour, Wool Technology Sheep Breed., 48(4) (2000) 303-312.

[5] J. Stepanović, S. Golubović, D. Trajković, M. Stamenković, Analiza prekidnih karakteristika pamučnih končanih pređa, Zbornik radova 19, Tehnološkog fakultet, Leskovac, (2009) 281-288.

[6] Y. P. Zhang, X. G. Wang, N. Pan, R. Postle, Weibull analysis of the tensile behavior of fibres with geometrical irregularities, Journal of Materials Science, 37(7) (2002) 1401-1406.

[7] D. Radivojević, M. Đorđević, D. Trajković, Ispitivanje tekstila, Visoka strukovna škola za tekstil, Leskovac, 2016., p. 205.

[8] С. М. Кирюхин, Ю. С. Шустов, Текстильное материаловедение, КолосС, Москва, 2011., р. 147.

Izvod

\section{ANALIZA MEHANIČKIH KARAKTERISTIKA POLIESTERSKIH ŠIVAĆIH KONACA IZ ŠTAPELNIH VLAKANA}

Nenad Ćirković, Nataša Stamenković, Tatjana Šarac, Jovana Stepanović

Tehnološki fakultet, Leskovac, Srbija

Spajanje delova odevnih predmeta u industriji izrade odeće se najviše vrši šivaćim koncima od kojih poliesterski konci zauzimaju značajno mesto. Na mestima spajanja odnosno šivenja, zajedno sa šavovima i bodovima, konci treba na obezbede odevnom predmetu odgovarajuću komfornost. Od njihovih karakteristika zavisiće i karakteristike šavova. U radu su analizirani poliesterski konci iz štapelnih vlakana, podužnih masa od 23 tex do 48 tex. Prikazane su zavisnosti između mehaničkih karakteristika konaca i konaca u petlji kao i njihovi međusobni odnosi odgovarajućim koeficijentima. Dobijeni rezultati mogu poslužiti proizvođačima šivaćih konaca i odeće u projektovanju i izboru konaca u svrhu prognoziranja mehaničkih karakteristika šavova na odevnim predmetima.
(ORIGINALNI NAUČNI RAD) UDK 677.072.6:677.494.674

Ključne reči: poliesterski konac, mehaničke karakteristike konca i konca u petlji 